\title{
É. Gherardi, Le Théâtre italien, Tome I, N. Marque (éd.)
}

\section{Monica Pavesio}

\section{(2) OpenEdition}

1 Journals

\section{Edizione digitale}

URL: http://journals.openedition.org/studifrancesi/9943

DOI: 10.4000/studifrancesi.9943

ISSN: 2421-5856

Editore

Rosenberg \& Sellier

\section{Edizione cartacea}

Data di pubblicazione: 1 août 2017

Paginazione: 356

ISSN: 0039-2944

\section{Notizia bibliografica digitale}

Monica Pavesio, «É. Gherardi, Le Théâtre italien, Tome I, N. Marque (éd.)», Studi Francesi [Online], 182

(LXI | II) | 2017, online dal 01 août 2017, consultato il 05 janvier 2021. URL: http://

journals.openedition.org/studifrancesi/9943 ; DOl: https://doi.org/10.4000/studifrancesi.9943

Questo documento è stato generato automaticamente il 5 janvier 2021.

\section{(c) (i) (9)}

Studi Francesi è distribuita con Licenza Creative Commons Attribuzione - Non commerciale - Non opere derivate 4.0 Internazionale. 


\title{
É. Gherardi, Le Théâtre italien, Tome I, N. Marque (éd.)
}

\author{
Monica Pavesio
}

\section{NOTIZIA}

ÉVARISTE GHERARDI, Le Théâtre italien, Tome I, édition de N. Marque, préface de Ch.

Mazouer, Paris, Classiques Garnier, 2016, 1022 pp.

1 Il Théâtre italien di Gherardi rappresenta una delle migliori testimonianze della fusione tra la tradizione italiana della commedia dell'arte e il teatro francese di metà Seicento. Dopo la cacciata della troupe italiana da Parigi, l'Arlecchino Evaristo Gherardi pubblica una raccolta di cinquantacinque pièces del repertorio dell'Ancien Théâtre Italien. Dopo una serie di vicissitudini che portano al proliferare di edizioni pirata e di pièces separate, la prima edizione ufficiale, riconosciuta da Gherardi, esce nel 1700 in sei volumi. La raccolta ebbe una serie di riedizioni settecentesche, per poi cadere nel più completo oblio.

Il primo volume di questa prima edizione moderna contiene undici commedie: Arlequin Mercure Galant, Arlequin Grapignan, Arlequin lingère du Palais, Arlequin Protée, Arlequin empereur dans la lune, Arlequin Jason, Arlequin Chevalier du Soleil, Isabelle médecin, Colombine avocat pour et contre, Le Banqueroutier, La Précaution inutile. Le pièces sono precedute da una breve prefazione scritta da Charles Mazouer e da un'introduzione da lui redatta in collaborazione con Nathalie Marque, che ripercorre i successi del teatro italiano in Francia e descrive i rapporti fra gli attori dell'Ancienne troupe e i drammaturghi francesi che con essi collaborarono. Le pièces sono precedute da una presentazione e sono corredate da note esplicative, varianti, partiture musicali, riproduzioni di frontespizi; un glossario, una bibliografia e un indice dei nomi sono posti in chiusura. 